\title{
Insakralitas Pemilihan Jodoh Dalam Pernikahan Keluarga Kontemporer
}

\author{
Anisa Puspa Rani ${ }^{1}$, Dwi Setiawan Chaniago, Syarifuddin \\ Universitas Mataram
}

\begin{abstract}
The shifting pattern of marriage is essentially not only in the process or the determination of mere matches. Further impacts on achieving the family's own goals and functions. Nowadays, various forms of disorganization in the family are common. The high problems in the family are not separated from the input of the marriage process that is in the assumption of the researcher due to the insacramalization of marriage. The purpose of this research is to know the cause of marriage insakrality in the election of the soul mate in contemporary families and identify forms of marriage insakrality in the election of the match in contemporary families. The study uses an interactionist sociological perspective focusing on identifying the person's knowledge, experience, wishes and consideration in choosing a soul mate and marriage. The results of the study showed the form of marriage insakality in the selection of the match in contemporary families can be seen from the eligibility indicators seen in the two main dimensions, the capability (capability) of prospective spouse with Consideration of religious aspects, and economic aspects. While the second dimension is allowed or not the selected spouse and marriage are held. The cause of marital insakality in the election of a match in contemporary families distinguished in two forms, the first insakrality caused not to match the chosen mate, both the insakrality caused by the missinterpretation in the understand the circumstances of sosio-culture.
\end{abstract}

Keywords : Insacrality, Match Selection, Marriage

\begin{abstract}
Abstrak
Pergeseran pola pernikahan pada dasarnya tidak hanya dalam proses maupun penentuan jodoh semata. Lebih jauh berdampak pada pencapaian tujuan dan fungsi keluarga itu sendiri. Dewasa ini, berbagai bentuk disorganisasi dalam keluarga lazim ditemui. Tingginya persoalan-persoalan dalam keluarga tidak terlepas dari input dari proses pernikahan yang dalam asumsi peneliti akibat terjadinya insakralisasi pernikahan. Adapun tujuan penelitian ini yakni mengetahui penyebab insakralitas pernikahan dalam pemilihan jodoh pada keluarga kontemporer dan mengidentifikasi bentuk-bentuk insakralitas pernikahan dalam pemilihan jodoh pada keluarga kontemporer. Penelitian ini menggunakan perspektif sosiologi interaksionis dengan berfokus mengidentifikasi pengetahuan, pengalaman, keinginan dan pertimbangan seseorang dalam memilih jodoh dan pernikahan. Hasil penelitian menunjukkan bentuk insakralitas pernikahan dalam pemilihan jodoh pada keluarga kontemporer dapat dilihat dari indikator eligibilitas yang dilihat dalam dua dimensi utama yakni kemampuan (kapabilitas) calon pasangan dengan mempertimbangkan aspek keagamaan, dan aspek ekonomi. sedangkan dimensi kedua adalah boleh atau tidak pasangan dipilih dan pernikahan dilangsungkan. Penyebab insakralitas pernikahan dalam pemilihan jodoh pada keluarga kontemporer dibedakan dalam dua bentuk, pertama insakralitas yang
\end{abstract}

\footnotetext{
${ }^{1}$ anisapusparani@unram.ac.id
} 
disebabkan tidak eligiblenya jodoh yang dipilih, kedua insakralitas yang disebabkan oleh miss-interpretasi dalam memahami keadaan sosio-kultural.

Kata Kunci : Insakralitas, Pemilihan Jodoh, Pernikahan

\section{Pendahuluan}

Pernikahan adalah proses institusionalisasi hubungan sosial keluarga. Proses institusionalisasi tersebut tidak terlepas dari pengaruh legitimasi sosialbudaya, dan hukum pada setiap masyarakat. Sebagai salah satu lingkaran kehidupan, proses pernikahan merupakan mekanisme ideal untuk melegitimasi hubungan seksual dalam menopang regenerasi dan eksistensi masyarakat secara luas. Berbicara tentang pernikahan sebagai titik tolak keluarga tidak bisa dipandang sebagai unit terkecil yang terdiri atas suami-istri dan anak saja. Lebih jauh, harus dipahami sebagai sebuah sistem sosial yang lebih luas, yakni masyarakat (Goode, 1995: 63). Adalah konsekwensi dari keluarga dipandang sebagi unit kolektif masyarakat, maka proses pernikahan itu sendiri tidak pernah bisa dipisahkan dari konstruksi sosial-budaya masyarakat.

Tidak dapat dipungkiri, pernikahan sebagai mekanisme utama dalam mewujudkan keluarga mengalami berbagai pergeseran dan perubahan. Salah satu dimensi pergeseran yang dapat dirasakan adalah semakin melemahnya ketergantungan (dependensi) seorang individu terhadap keluarga inti maupun keluarga luas. Dahulu, pemilihan jodoh melibatkan mekanisme sosial budaya yang ditentukan oleh keluarga luas, bahkan masyarakat dengan mempertimbangkan kualitas individual, sosial dan budaya. Adanya pertimbangan "bibit, bebet, dan bobot" merupakan salah satu contoh berlaku prinsip-prinsip perkawinan yang menjadi alat kontrol dalam pemilihan jodoh. Sehingga Adanya kecenderungan keluarga menentang pernikahan yang cenderung dianggap merendahkan keluarganya (Goode, 1995: 74)

Sebaliknya, dewasa ini yang terjadi dalam proses pernikahan bahkan dalam pencarian jodoh sifat independensi anak lebih dominan dari pada orang tua ataupun keluarga. Hal ini ini disebabkan pola pikir yang adaptif, bahwa pernikahan akan dijalani oleh anak itu sendiri. Adalah hal yang logis dalam pemilihan jodoh menjadi domain otoritas anak. Pada kondisi ini, tidak mengherankan pertimbangan personal anak dalam pemilihan jodoh untuk pernikahan lebih didasari pertimbangan ketertarikan fisik, rasa nyaman dan cinta, serta dan harapan-harapan kebahagian dalam perspektif anak itu sendiri. Pada tahaf ini, pemilihan jodoh sebagai domain orang tua dan keluarga dipandang tidak relevan. 
Perubahan rasionalitas dalam proses pemilihan jodoh dari semula identik dengan dependensi anak terhadap orang tua dan keluarga menjadi independensi, tidak terlepas dari perubahan pola pernikahan itu sendiri. Dahulu pernikahan berpola owner proverty. Artinya, anak perempuan setelah menikah menjadi hak milik suami secara penuh. Peran istri sebagai owner proverty ditentukan oleh suami secara mutlak. Istri mengemban kewajiban berbakti atas suami. Pola owner proverty umumnya berlaku pada masyarakat tradisional, dimana pemilihan jodoh menjadi sedemikian ketat dan terkontrol oleh orang tua dan keluarga. Hal tersebut bertujuan agar anak bisa mendapatkan pasangan yang tepat "bibit, bobot, bebetnya", untuk memastikan anak diperlakukan dengan baik dan mencapai kebahagiaan.

Pada masyarakat kontemporer, pola pernikahan relatif lebih dinamis. Banyak berkembang pola-pola baru pernikahan seperti saling melengkapi (head complement), pola pernikahan senior-junior partner, hingga equal partner. Pada ketiga pola ini, posisi istri dalam keluarga relatif mendapatkan kedudukan yang lebih bersifat diferensiasi bahkan seimbang dengan suami. Sehingga anak dalam proses pemilihan jodoh lebih dominan menentukan, sebab mereka yang akan menjalani hubungan yang lebih mengedepankan komitmen pribadi dibandingkan hubungan-hubungan suami istri yang terstratifikasi. Hal tersebut tentu membawa konsekwensi pada melemahnya peran orang tua dan keluarga dalam proses pemilihan jodoh dan pernikahan.

Pernikahan merupakan media sekaligus representasi keingingan mencapai harapan-harapan ideal dalam fungsi-fungsi keluarga. Pernikahan sejatinya menjadi saluran bagi tercapainya fungsi pokok keluarga yang meliputi fungsi biologis, afeksi, sosialisasi, edukasi, proteksi dan rekreasi. Kendati secara prinsip tujuan pokok pernikahan adalah untuk memfasilitasi kebahagiaan berdasarkan fungsifungsi keluarga tidak berubah, namun perspektif dalam mencapai fungsi-fungsi keluarga itu sendiri cenderung berubah menjadi otonomi anak dimana determinasi orang tua dan keluarga semakin melemah.

Pergeseran pola pernikahan pada dasarnya tidak hanya dalam proses maupun penentuan jodoh semata. Lebih jauh berdampak pada pencapaian tujuan dan fungsi keluarga itu sendiri. Dewasa ini, berbagai bentuk disorganisasi dalam keluarga lazim ditemui. Perceraian, pernikahan dini, kekerasan dalam rumah tangga, penelantaran, dan bentuk anomali lain cenderung mengalami peningkatan. Perceraian misalnya, pada tahun 2015 total di Indonesia Pengadilan Tinggi Agama mencatat 382.231 kasus (Data Kemenag.go.id), tentu jika diasumsikan dengan perceraian yang tidak tercatat di Pengadilan Agama akan jauh lebih besar lagi. Khususnya untuk wilayah Provinsi Nusa Tenggara Barat, jumlah angka perceraian 3.137 kasus. Sedangkan data kekerasan terhadap perempuan dan anak di Provinsi NTB juga termasuk yang tinggi, yakni 1.572 kasus, dimana umumnya terjadi di lingkungan keluarga (Data BP3AKB, Provinsi Nusa Tenggara Barat Tahun 2015). 
Sedangkan angka pernikahan dini di Provinsi Nusa Tenggara Barat tertinggi nomor dua di Indonesia, yakni mencapai $51 \%$ dari total pernikahan yang tercatat secara resmi (Data BKKBN Prov. NTB tahun 2016).

Tingginya persoalan-persoalan dalam keluarga tidak terlepas dari input dari proses pernikahan yang dalam asumsi peneliti akibat terjadinya insakralisasi pernikahan. Tidak mengherankan jika pada beberapa masyarakat yang cenderung skeptis dengan pola pernikahan kontemporer yang relative mengedepankan unsur afeksi, rasa sayang dan cinta namun tidak jarang berujung dengan berbagai anomali di dalam keluarga. Tingginya berbagai persoalan yang terjadi dalam keluarga kontemporer menjadi indikasi dari outcome insakralitas pernikahan dimana rasionalitas dan kesakralan pernikahan telah terdegradasi. Insakralitas pernikahan dikhawatirkan lambat laun akan menjadi boomerang bagi institusi pernikahan dan keluarga.

\section{Metode Penelitian}

Penelitian ini dilakukan di Kelurahan Sekarteja, Kecamatan Pringgasela, Kabupaten Lombok Timur Provinsi Nusa Tenggara Barat (NTB). Pemilihan lokasi tersebut didasari oleh pertimbangan temuan dalam observasi awal yang menunjukkan terjadinya disorganisasi di dalam keluarga. Penelitian ini menggunakan metode penelitian kualitatif. Teknik pengumpulan data yang dipergunakan adalah wawancara mendalam dan focus group discussion (FGD). Informan yang diwawancara berjumlah 15 orang informan yang terdiri atas keluarga dengan pasangan yang menikah di bawah usia 20 tahun (standar acuan usia pendewasaan pernikahan di Provinsi NTB), remaja, tokoh masyarakat dan penghulu, serta aparatur desa.

Informasi yang dihimpun berupa deskripsi pertimbangan subyektif dalam pemilihan jodoh, pemaknaan tentang jodoh, pernikahan dan hubungan suami istri, pengetahuan tentang kesakralan pernikahan dan keluarga, pemahaman dalam membangun, menjalankan dan mempertahankan keluarga, serta rasionalitas tentang tujuan yang ingin dicapai dalam fungsi keluarga. Semua informasi yang dihimpun tersebut merupakan pemahaman subyektif pelaku yang akan diinterpretasikan dalam analisis domain-taksonomi.

\section{Landasan Teoritis}

Pada disiplin sosiologi dikenal tiga paradigma yang dipergunakan dalam memahami realitas sosial, yakni fakta sosial, definisi sosial, dan perilaku sosial (Ritzer, 2010:6-10). Pada penelitian ini, landasan teori yang dipergunakan yakni berdasarkan paradigma definisi sosial sebagaimana diungkapkan oleh Weber. Dalam paradigma definisi sosial, manusia dipandang sebagai makhluk yang aktif dan kreatif yang menciptakan dunianya. Paradigma definisi sosial dalam memahami 
realitas sosial berfokus pada upaya memahami tindakan sosial, yakni sebagai perbuatan yang memiliki makna atau arti subyektif bagi individu sebagai aktor dan kreator dalam hubungan sosialnya.

Paradigma definisi sosial memahami individu sebagai makhluk sosial yang unik dan spesifik, sehingga dalam memahami realitas sosial tersebut, pemahaman individu menjadi obyek utama yang menjadi fokus perhatian utama (Damsar, 2015: 41). Gejala sosial dipahami sebagai realitas yang terbentuk atas pemahaman internal individu. Sehingga memahami individu berarti memahami pengetahuan, pemahaman, dan pemaknaan individu sebagai pembentuk utama realitas sosial. Jadi fokus utama yang menjadi perhatian utama dalam paradigma definisi sosial yakni :

a. Mencari aspek-aspek pemikiran, pengetahuan dan pengalaman individu tentang realitas sosial yang dibangun.

b. Membangun empati terhadap objek atau permasalahan yang diteliti dalam upaya memahami aspek individual yang meliputi arti, dan makna suatu tindakan atau gejala sosial bagi individu.

c. Memberikan penjelasan-penjelasan subyektif dan intersubyektif individu yang merupakan hasil konstruksi dan repoduksi pemahaman manusia tentang suatu gejala sosial.

Salah satu teori yang tergabung dalam paradigma definisi sosial yang relevan dengan persoalan keluarga diteliti yakni teori interaksionisme simbolik. Pendekatan interaksionisme simbolik dalam memahami fenomena keluarga berfokus pada upaya memahami tindakan berdasarkan rasionalitas dan makna subyektif bagi individu. Komponen dalam keluarga dalam hubungan interaksinya memiliki pemahaman dalam mengartikan setiap tindakan yang dilakukan. Pemahaman tersebut terbentuk dari berbagai proses sosialisasi dan habitualisasi dalam kehidupan masyarakat yang telah terinternalisasi menjadi bagian diri berupa stock of knowledge. Pemahaman itu pula yang menjadi indikator bagi setiap individu dalam memahami, memaknai dan menginterpretasikan suatu perbuatan.

Relasi sosial dalam keluarga juga terbentuk atas dasar pemahaman kolektif yang terbangun melalui proses pemaknaan. Pemaknaan kolektif tersebut berarti selain dipahami oleh diri sendiri secara subyektif, juga dipahami oleh masyarakat pada umumnya. Sehingga makna menjadi pemersatu dalam mengartikan dan menginterpretasikan harapan, peran dan kewajiban di dalam keluarga. Interaksi dan tindakan sosial dalam keluarga dan masyarakat terbangun, berjalan dan dipertahankan berdasarkan makna-makna yang dipahami secara kolektif. Dalam hubungan interaksi dalam keluarga tersebut, keluarga senatiasa terorganisir dalam suatu pemahaman yang bertumbuh, berubah dan beradaptasi sesuai dengan perkembangan kondisi masyarakat.

Dalam memahami insakralitas pemilihan jodoh dalam pernikahan keluarga modern dalam pernikahan berfokus pada pemaknaan anggota keluarga dalam proses 
pernikahan dan arti keluarga. Dalam kondisi perubahan sosial dalam keluarga, maka makna yang terkandung dalam relasi sosial di dalam keluarga juga mengalami pergeseran. Hal tersebut tidak terlepas dari proses sosialisasi dan habitualisasi masyarakat yang cenderung direproduksi dalam mengikuti perkembangan dinamika masyakat. Dampaknya kesadaran kolektif dalam masyarakat cenderung berubah, yang pada akhirnya berimplikasi pada kesadaran individual dalam bertindak.

Pada pendekatan interaksionis, ciri teoritis utama dalam memahami realitas sosial dalam pemilihan jodoh pada pernikahan keluarga kontemporer berfokus pada makna dan arti yang dipahami individu dalam proses interaksi kesehariannya. Pemaknaan tersebut cenderung senantiasa dimodifikasi dan diadaptasi oleh anggota keluarga dan ditiru dalam mengambil peran (role taking), dan memainkan peran (role playing) (Ihromi, 2004: 276). Jadi pergeseran dalam pemaknaan yang menciptakan insakralitas dalam pemilihan jodoh pada pernikahan tidak terlepas dari pemaknaan masyarakat dalam memahami realitas sosial dalam pemilihan jodoh, dalam mencapai tujuan dan fungsi keluarga, serta cara memperolehnya merupakan representasi dari pemahaman subyektif yang dibangun secara kolektif. Jadi dalam pendekatan teori interaksionis fokus utama terhadap perkembangan pemahaman subyektif, pembentukan kebiasaan, pengetahuan dan rasionalitas dalam berperan di dalam keluarga.

\section{Fenomena Pemilihan Jodoh Keluarga Kontemporer}

Keluarga merupakan unit sosial terkecil di dalam masyarakat. Keluarga merupakan manifestasi hubungan peran (role relations) antara seorang laki-laki dan perempuan yang diikat oleh pernikahan. Hubungan tersebut adalah manifestasi pertukaran fungsi bagi anggota keluarga baik secara biologis, ekonomis, afektif, sosial dan fungsi lainnya yang diakui oleh masyarakat. fungsi tersebut tidak hanya menggambarkan hubungan internal dalam suatu rumah tangga, melainkan bagian integral jaringan sosial yang lebih besar. Sehingga keluarga dikatakan sebagai miniature masyarakat.

Keluarga merupakan salah satu objek kajian sosiologis yang substansial dipahami dalam memahami berbagai realitas sosial. Kebaikan dan ketentraman di dalam masyarakat akan selalu terwujud jika setiap orang mampu bertindak "benar" di dalam keluarga (Confusius, dalam Goode, 1995: 2). Hal tersebut bermakna pula bahwa berbagai persoalan yang terjadi di lingkungan masyarakat merupakan hasil anomali yang terjadi di dalam keluarga. Berbagai persoalan seperti kemiskinan, perceraian, kenakalan remaja, disorganisasi keluarga, dan beragam persoalan lainnya merupakan bentuk-bentuk persoalan yang dapat muncul ketika peran dan fungsi di dalam keluarga tidak berjalan sebagaimana mestinya.

Hampir pada setiap bentuk masyarakat, pernikahan menjadi mekanisme yang diakui untuk berkeluarga. Pernikahan merupakan bentuk proses pelembagaan 
hubungan keluarga. Proses pelembagaan tersebut berguna untuk meminimalisir kecenderungan naluri biologis yang amoral yakni seks bebas. Untuk itu, pernikahan hampir selalu merupakan proses budaya dimana setiap individu berusaha menyesuaikan kebutuhan sosial yang diwujudkan melalui pernikahan agar mendapat legitimasi secara sosial dan budaya. Kendati legitimasi budaya merupakan salah satu faktor esensial dalam menjamin keberhasilan suatu pernikahan, ada aspek lain yang harus terpenuhi untuk mencapai tujuan keluarga.

Secara sosiologis, salah satu faktor yang menentukan keberhasilan rumah tangga atau keluarga adalah pemilihan jodoh serta kondisi sosio-kultural yang melatarbelakanginya. Menurut Robert Winch, dalam pemilihan jodoh setiap orang mencari seseorang calon yang dalam perkiraannya dapat menjadi jawaban akan harapan-harapan dalam memenuhi kebutuhannya (dalam Goode, 1995: 77). Kendati demikian, tidak dapat dipungkiri perubahan sosial berimplikasi terhadap proses pemilihan jodoh yang memperbesar peran individu dibandingkan pengaruh keluarga dan lingkungan sosio-kultural. Meskipun bukan sesuatu yang dilarang, namun proses lahirnya keluarga melalui proses pemilihan jodoh dengan peran dominan individu menuntut berbagai pertimbangan dan individu harus cukup dewasa termasuk secara sosial untuk mampu secara agamis, ekonomis, serta keberlangsungan fungsi hubungan sosial baik di dalam keluarga, serta masyarakat.

Pemilihan jodoh pada masyarakat kontemporer merupakan arena tarik menarik antara ranah individual dan keluarga dengan tuntutan kondisi sosiokultural. Meskipun ada tendensi bahwa dewasa ini pemilihan jodoh telah menjadi ranah privat bagi individu yang ingin menikah. Pertimbangan cinta, kasih sayang dan hubungan emosional dann afektif menjadi salah satu dasar paling dominan bagi pemilihan jodoh yang menentukan pernikahan bagi keluarga kontemporer. Tendensi gerak dominan pertimbangan personal dalam proses pemilihan jodoh sekaligus berdampak pada semakin menipisnya pengaruh nilai kolektif seperti peran-peran keluarga luas, serta pertimbangan sosio-kultural seperti agama, hukum, ekonomi dan lain sebagainya.

Pergeseran dalam berbagai pertimbangan yang mempengaruhi preferensi seseorang dalam memilih jodoh akan berimplikasi pada banyak hal. Hal tersebut mengingat bahwa keluarga merupakan unit sosial yang terorganisir secara integral dengan masyarakat. Artinya berbicara hubungan dalam keluarga tidak hanya mengenai hubungan suami-istri, orang tua anak, serta hubungan internal dalam keluarga lainnya. Lebih jauh berkenaan dengan jaringan struktur sosial di dalam masyarakat. Oleh karena itu, proses pemilihan jodoh tidak dapat dilihat sebagai proses hubungan emosional dan afeksi percintaan semata, kendati demikian ada peran dan pengaruh kondisi sosio-kultural yang perlu dipertimbangkan dalam proses penentuan jodoh tersebut. 
Pernikahan merupakan salah satu instrumen yang menentukan keberlangsungan masyarakat. Oleh sebab itu, hampir pada semua bentuk masyarakat terdapat banyak aturan dan regulasi yang mengatur proses pemilihan jodoh hingga pernikahan tersebut. Aturan informal yang berlaku dalam kebiasaan, adat istiadat, hingga hukum pernikahan yang formal merupakan representasi bahwa proses pernikahan memerlukan berbagai macam legitimasi sosial. Hal tersebut tidak terlepas dari adanya dampak-dampak yang mungkin ditimbulkan ketika proses pemilihan jodoh, pernikahan dan hubungan dalam keluarga tidak berjalan sebagaimana diharapkan, sehingga masyarakat memiliki tanggungjawab moral untuk memastikan berbagai kondisi anomali tersebut terjadi.

Berbagai aturan yang mendasari proses pemilihan jodoh dan pernikahan baik secara sosio-kultural maupun sebagaimana diatur dalam hukum formal pernikahan telah mendorong seseorang yang ingin menikah untuk mampu mempertimbangkan berbagai aspek seperti pertimbangan agama, ekonomi, sosial, hukum, kesehatan dan lain sebaginya sebelum memutuskan untuk menikah. Pertimbangan tersebut merupakan representasi kesakralan proses pernikahan sebab guna memastikan pernikahan yang dilakukan terlegitimasi oleh lingkungan sosiokultural dan hukum negara, serta dapat memperoleh dampak yang positif. Sebaliknya, proses pernikahan dengan atau kurang mempertimbangkan berbagai hal mengindikasikan terjadinya proses insakralitas dalam pemilihan jodoh dan pernikahan yang dalam hal ini bisa beresiko pada munculnya berbagai persoalan di dalam keluarga seperti perceraian, kekerasan dalam rumah tangga, disorganisasi keluarga serta berbagai persoalan lainnya yang sering terjadi di masyarakat.

\section{Insakralitas Pernikahan Dalam Pemilihan Jodoh Pada Keluarga Kontemporer}

Pada dasarnya, proses pemilihan jodoh melibatkan berbagai proses penilaian baik secara personal, keluarga dan masyarakat. Penilaian-penilaian tersebut merupakan aspek ideal yang harus dipertimbangkan dalam pemilihan jodoh dan pernikahan. Pada masyarakat yang menganut nilai-niai ketimuran lebih mensakralkan proses pemilihan jodoh dan pernikahan dengan penuh pertimbangan. Pertimbangan dalam menentukan jodoh dalam pernikahan menuntut seseorang untuk bisa selektif dalam memilih jodoh.

Sebagai proses dalam lingkaran kehidupan yang idealnya berlangsung sekali dalam seumur hidup, pernikahan menuntut seseorang untuk mampu mempertimbangkan berbagai hal sebelum memuntuskan menikah. Setiap masyarakat memiliki berbagai aspek ideal yang harus dipenuhi dalam memilih jodoh hingga memutuskan untuk menikah. Beberapa hal yang patut untuk dipertimbangkan adalah faktor agama, faktor ekonomi, faktor latar belakang keluarga, faktor hukum, faktor kesehatan serta kondisi sosio-kultural lainnya. Berdasarkan hasil penelitian diketahui bahwa proses pemilihan jodoh tergolong 
mengalami insakralitas berdasarkan dua indikator eligibilitas berdasarkan aspek yang perlu dipertimbangkan dalam pemilihan jodoh dan pernikahan. Indikator tersebut meliputi kemampuan (kapabel), serta boleh atau tidak suatu pernikahan dilangsungkan..

Insakralitas dalam pemilihan jodoh dapat dilihat dari indikator kemampuan (kapabilitas). Untuk mengukur kemampuan pasangan dalam pemilihan jodoh, ada beberapa aspek yang perlu dipertimbangkan, diantaranya aspek agama,dan aspek ekonomi. Aspek agama misalnya, berdasarkan hasil penelitian diketahui bahwa faktor agama adalah hal utama yang harus dipertimbangkan dalam pemilihan jodoh. Aspek agama adalah hal utama yang harus dipertimbangkan ketika memutuskan untuk menikah. Harapannya dengan pemahaman agama yang baik maka rumah tangga yang dijalani dapat sesuai dengan apa yang telah diatur oleh agama sehingga dapat meminimalisir hal-hal yang tidak diharapkan.

Ada banyak hal yang perlu dipertimbangkan seperti menikah dengan pasangan yang seagama, bisa sholat dan mengaji serta pemahaman keagamaan lainnya. Argumentasi tersebut tentunya menunjukkan sakralitas dalam pemilihan jodoh dimana agama menjadi faktor utama yang harus dipertimbangkan dalam memilih jodoh dan pernikahan. Kendati demikian, berdasarkan hasil penelitian diketahui bahwa aspek insakralitas dalam pemilihan jodoh justru terdapat pada pemahaman tentang takdir yang dipahami secara fatalistik.

Aspek keagamaan merupakan faktor paling utama tetapi dengan pertimbangan rasionalitas paling sederhana. Pemahaman akan takdir cenderung fatalistik dan tersimplifikasi (disederhanakan). Hal tersebut dapat dilihat dari pemahaman tentang jodoh, rezeki dan maut yang telah ditetapkan, mendorong individu bersifat pasif terhadap takdir terkhusus untuk faktor ekonomi dan kesehatan. Meskipun dalam menentukan jodoh terdapat beberapa pertimbangan ideal, namun dalam kondisi riil tidak selalu terpenuhi. Kondisi fatalistik dalam melihat jodoh sebagai sebuah takdir yang tidak dapat dirubah. Sehingga jika interaksi sosial dan proses pergaulan dengan seseorang mengarah kehubungan yang serius maka hal tersebut telah dianggap ketetapan takdir. Dalam hal ini rasionalitas akan berbagai pertimbangan menjadi tidak terwujud.

Pemahaman keagamaan akan takdir juga cenderung tersimplifikasi (disederhanakan). Meskipun pemahaman agama menjadi suatu tuntutan utama, namun dalam pemahaman yang sederhana tanpa mempertimbangkan lebih jauh ajaran agama tentang takdir yang dapat dirubah dan takdir yang tidak dapat dirubah (Qada' dan Qadar). Sehingga ketika ada seseorang melamar akan memunculkan pemikiran bahwa seseorang tersebut adalah takdirnya.

Insakralitas dalam pemilihan jodoh yang kedua dapat dilihat dari indikator kemampuan (kapabilitas) dalam aspek ekonomi. Aspek ekonomi yang dimaksud adalah berbagai pertimbangan tentang pekerjaan, penghasilan dan kemapanan, 
status sosial, dan lain sebagainya. Tidak dapat dipungkiri, faktor ekonomi merupakan aspek yang utama setelah faktor agama sebagai standarisasi bagi seseorang untuk dikatakan mampu (kapabel) menikah. kemampuan ekonomi penting untuk memastikan kesejahteraan pasca pernikahan. Selian itu, dalam rumah tangga terkandung kewajiban untuk memenuhi kebutuhan ekonomi keluarga berupa sandang, pangan dan papan.

Pernikahan merupakan salah satu bentuk pengharapan untuk bisa memenuhi kebutuhan ekonomi, sehingga penting untuk bisa memastikan jodoh yang dipilih memiliki status ekonomi yang baik. Kelompok usia muda cenderung lebih permisif dalam melihat status ekonomi dalam menilai seseorang bisa dikatakan mampu untuk dijadikan jodoh. Pekerjaan dianggap penting namun yang utama adalah terpenuhinya kebutuhan hariannya. Pemahaman tentang ekonomi tersebut juga melekat dengan anggapan takdir sebagai sebuah ketetapan. Anggapan bahwa rezeki telah diatur, sehingga kesiapan seseorang berdasarkan pertimbangan ekonomi lebih dilihat dari keinginannya untuk bekerja.

Kemampuan ekonomi tidak diukur dengan standar kemapanan. Meskipun faktor ekonomi menjadi pertimbangan ideal yang penting, namun dalam kenyataannya aspek ekonomi semisal pekerjaan, penghasilan dan kemapanan masih bisa ditolerir dengan berbagai rasionalitas seperti ketertarikan afeksi dan kenyamanan emosional. Faktor ekonomi tersebut juga ditolerir dalam pengertian status ekonomi tidak harus dituntut pra pernikahan, melainkan bisa diusahakan secara bersama pasca pernikahan

Peran perempuan penting sebagai proyeksi rumah tangga di masa depan. Komitmen dan kesanggupan bagi perempuan untuk turut membantu dan berbagi peran dalam memenuhi kebutuhan ekonomi keluarga sangat diperlukan. Selain itu, dalam proses pernikahan, biaya ekonomis hampir dominan tidak dipermasalahkan karena masih menjadi tanggungjawab orang tua. Anggapan bahwa mempermasalahkan dan mempertanyakan urusan ekonomi pra pernikahan dianggap sesuatu yang tidak etis dikarenakan rezeki bagi pasangan yang telah menikah telah diatur oleh Tuhan YME.

Insakralitas dalam pemilihan jodoh dapat dilihat dari indikator boleh atau tidak suatu pernikahan dilakukan. Untuk mengetahui suatu pernikahan diperbolehkan atau tidak maka ada beberapa faktor yang harus dipertimbangkan dalam memilih jodoh hingga melangsungkan proses pernikahan. Faktor yang dimaksud adalah aspek sosio-kultural, aspek hukum, dan aspek kesehatan. Kondisi sosio-kultural, aturan hukum dan kondisi kesehatan merupakan indikator kelayakan seseorang untuk dijadikan jodoh.

Insakralitas dalam pemilihan jodoh yang kedua dapat dilihat dari indikator boleh atau tidak suatu pernikahan berlangsung. Prasayarat ini mengacu pada pertama pertimbangan-sosio-kultural yang utama adalah restu orang tua/kerabat 
serta latar belakang keluarga. Dalam pemilihan jodoh, anak lebih dominan dalam menentukan pasangan yang dikehendaki berdasarkan hasil interaksi sosial yang dijalani. Sedangkan aspek terkait faktor sosio-kultural lainnya adalah latar belakang keluarga yang seringkali dijadikan pedoman apakah suatu pasangan direstui atau diperbolehkan dalam memilih jodoh.

Latar belakang keluarga tidak menjadi hal yang dipersoalkan dalam pemilihan jodoh pada keluarga kontemporer. Pertimbangan dalam pemilihan jodoh dilihat dari latar belakang keluarga tidak terlalu dituntut. Hal yang diperhatikan lebih pada kecocokan dan keinginan masing-masing pihak dalam melihat anak bahagia. Selain itu dikarenakan setelah berumah tangga setiap anak dituntut untuk mampu mandiri dan komitmen atas keputusan yang telah diambil.

Insakralitas dalam pemilihan jodoh dapat dilihat dari indikator boleh atau tidak suatu pernikahan berlangsung mengacu pada aspek hukum. Berdasarkan sistem hukum yang berlaku di Indonesia, yakni Undang-Undang Pernikahan Nomor 1 tahun 1974 tentang perkawinan, terkhusus pada pasal 7 ayat 1 mengatur tentang batas minimal usia pernikahan, yakni 16 tahun bagi perempuan dan 19 tahun bagi laki-laki. Secara formal, regulasi tersebut menjadi pedoman utama, namun di dalam masyarakat, standar ajaran keagamaan juga berlaku yakni mengenai usia baligh sebagai indikator pernikahan boleh berlangsung.

Kendati batas minimum usia pernikahan telah secara tegas menyebutkan usia yang diperbolehkan menikah, namun pada realitanya aturan tersebut masih sering dilanggar oleh beberapa anggota masyarakat. Umur merupakan indikator yang dilematis dalam proses pernikahan. Di satu sisi harus mengikuti aturan, namun di sisi lain berkenaan dengan masalah moralitas sehingga pada akhirnya dampak yang terjadi adalah pernikahan di bawah umur. Pada sebagian kalangan remaja dan masyarakat cenderung menyederhanakan (simplifikasi) batas umur yang tergolong dikatakan boleh (kapabel) untuk menikah. Anjuran agama tentang usia Baligh sebagai indikator minimum untuk menikah cenderung dipahami secara sederhana. Walaupun standar agama memberikan batasan baligh sebagai usia yang tergolong mampu untuk menikah. Namun perlu dipahami lebih lanjut bahwa dengan berbagai faktor usia baligh tersebut semakin dini, sehingga harus diimbangi dengan pendewasaan usia pernikahan yang mana baligh tidak menjadi syarat tunggal bagi seseorang untuk dikatakan boleh untuk menikah.

Selain batas usia minimum, aspek hukum yang harus dipertimbangkan adalah status pernikahan dalam hal ini adalah apakah jodoh yang dipilih berstatus telah menikah, janda atau duda. Hal tersebut selain untuk melihat legalitas pernikahan juga untuk memastikan pernikahan yang berlangsung tidak bertentangan dengan etika yang berlaku di dalam masyarakat. Kondisi pelik yang menunjukkan insakralitas dalam pemilihan jodoh yang tidak memperhatikan aspek hukum, dalam hal ini status pasangan. Hal tersebut tentu tidak hanya berdampak secara moral, 
namun lebih jauh berdampak pada hak-hak sebagai istri maupun anak. Apalagi jika ditarik dalam hukum agama yang hanya dibenarkan menikah maksimal dengan empat perempuan.

\section{Kesimpulan}

Bentuk insakralitas pernikahan dalam pemilihan jodoh pada keluarga kontemporer dapat dilihat dari indikator eligibilitas yang dilihat dalam dua dimensi utama yakni kemampuan (kapabilitas) calon pasangan dengan mempertimbangkan aspek keagamaan, dan aspek ekonomi. sedangkan dimensi kedua adalah boleh atau tidak pasangan dipilih dan pernikahan dilangsungkan. Bentuk insakralitas terjadi berdasarkan eligibilitas kemampuan terjadi dalam bentuk tidak optimalnya pertimbangan-pertimbangan keagamaan dan ekonomi dalam pemilihan jodoh dan pernikahan. Tidak eleigiblenya yang berujung pada insakralitas pemilihan jodoh dan pernikahan tersebut akibat kapabilitas keagamaan dan ekonomi lebih banyak tersimplikasi dengan anggapan jodoh dan rezeki sebagai takdir yang telah ditetapkan sehingga disikapi secara fatalis. Jika dilihat dari boleh atau tidaknya suatu pasangan dipilih dan pernikahan dilangsungkan melahirkan bentuk insakralitas dimana aspek sosio-kultural, dan aspek hukum yang belum dipertimbangkan secara optimal. 


\section{Daftar Pustaka}

Abdul Wahab. 2015. Tantangan Terhadap Institusi Pernikahan di Era Globalisasi.

Field David., Kepribadian Keluarga; Kanisius, Yokyakarta, 1992.

Horton B. Paul dan Chester L. Hunt., Sosiologi, Jilid I, Ed. 6, Erlangga, 1987.

Ihromi, T.O. Bunga Rampai Sosiologi Keluarga. Jakarta: Yayasan Obor Indonesia. 2004.

Indra S., Faktor-faktor Penting Dalam Kehidupan Keluarga Bahagia; BPK Gunung Mulia, Jakarta, 1980.

J. Van Paassen., Hukum Nikah Kanonik; STF. Seminari Pineleng, 1983.

Khairuddin H., Sosiologi Keluarga; Nur Cahaya, Cetakan I, 1985.

Mabe A. Elliot and Prancis E. Merrill; Sosial Disorganization; Harper \& Brothers, Publishers, New York, 1961.

Milda Itares. 2015. Fenomena Pernikahan Usia Muda di Pontianak.

Nur Kholisoh, dan Primayanti. 2016. Model Komunikasi Kelompok Tentang Makna Pernikahan Antargenerasi Di Kalangan Masyarakat Kelas Menengah Jakarta.

R.M. Mac Iver and Charles H. Page., Sosiety an Introductory Analysis; Mac Millan \& Co, Ltd, London, 1952.

Robert Biersted., The Science Of Sociology, 1957., dalam Selo Soemardjan dan Soelaeman

Soemardi., Setangkai Bunga Sosiologi; Yayasan Badan Penerbit FE-UI, Jakarta, 1964.

Soerjono Soekanto., Sosiologi Keluarga; Rineka Cipta, Jakarta,1990. 